DOI: https://doi.org/10.32839/2304-5809/2021-5-93-3

УДК 504.61

Пількевич Ю.Г.

Київський національний університет будівництва і архітектури

Розорінов Г.M.

Національний технічний університет України

«Київський політехнічний інститут імені Ігоря Сікорського»

Ткаченко T.M.

Київський національний університет будівництва і архітектури

\title{
РАДІОАКТИВНЕ ЗАБРУДНЕННЯ РИБ І ВИМІРЮВАННЯ МАЛИХ ІНТЕНСИВНОСТЕЙ ІОНІЗУЮЧИХ ВИПРОМІНЮВАНЬ
}

Анотація. Одним з важливих джерел забруднення риби є передача радіоактивних речовин через харчові ланцюги. Більшість риб харчуються планктоном, який здатний накопичувати радіонукліди до концентрацій в сотні і тисячі разів більше, ніж в навколишній воді. Тому при низькому вмісті радіоактивних речовин у воді їх споживання риби в першу чергу обумовлено зараженою їжею. При знаходженні у воді, що забруднена радіоактивними речовинами, риби отримають зовнішне опромінення. Адсорбована на поверхні їх тіла активність створюе опромінення організму. У свою чергу радіоактивні речовини, що накопичуються в органах і тканинах, створюють внутрішне джерело опромінення. Накопичення радіоактивних речовин органами i тканинами риб, а також розподіл і виділення їх залежить від цілого ряду умов, основними з яких е: хімічна природа радіоізотопів і періоди їх напіврозпаду, концентрація радіоізотопів у воді, вид, вік і фрізіологічний стан риб, екологічні умови. Кумуляція радіоізотопів органами і тканинами риб залежить від концентрації цих радіоізотопів у воді і часу перебування в ній риб. Чим вище ступінь радіоактивності води, тим більше ступінь забрудненості риб. Наведено деякі види риб, впорядковані за зростанням середнього рівня вмісту ${ }^{137} \mathrm{Cs}$. Запропоновано, обгрунтовано та експериментально перевірено методику вимірювання малих інтенсивностей іонізуючих випромінювань, засновану на вимірі $t$-поточних характеристик $n$-вимірних функцій розподілу ймовірностей часових інтервалів між імпульсами, що виробляються детекторами випромінювань. Показано, що розроблена методика дозволяе достовірно виявляти випромінювання з інтенсивностями в десятки разів нижче інтенсивності фонових випромінювань, при високих інтенсивностях фронового випромінювання. Застосування пропонованої методики в десятки разів зменшуе час аналізу і знижуе вимоги до екранування досліджуваних об'єктів від фронового випромінювання.

Ключові слова: забруднення, іонізуюче випромінювання, радіонукліди, риби.

Pil'kevych Yulii

Kyiv National University of Construction and Architecture Rozorinov Heorhii National Technical University of Ukraine "Igor Sikorsky Kyiv Polytechnic Institute" Tkachenko Tetiana Kyiv National University of Construction and Architecture

\section{RADIOACTIVE POLLUTION OF FISH AND MEASUREMENT OF SMALL INTENSITY OF IONIZING RADIATION}

Summary. One of the important sources of fish pollution is the transmission of radioactive substances through the food chains. Most fish feed on plankton, which is able to accumulate radionuclides to concentrations in hundreds and thousands of times more than in the surrounding water. Therefore, with a low conten $t$ of radioactive substances in water, their fish consumption primarily due to infected food. When found in water contaminated with radioactive substances, fish will be external irradiation. Adsorbed on the surface of their body activity creates irradiation of the body. In turn, radioactive substances accumulated in organs and tissues create an internal radiation source. The accumulation of radioactive substances by organs and tissues of fish, as well as the distribution and selection of them depends on a number of conditions, the main of which are: the chemical nature of radioisotopes and periods of half-life, the concentration of radioisotopes in water, type, age and physiological state of fish, environmental conditions. Cumulation of radioisotopes by organs and tissues of fish depends on the concentration of these radioisotopes in water and time of stay in it. The higher degree of water radioactivity results in the greater degree of fish pollution. Some types of fish arranged as an average level of ${ }^{137} \mathrm{CS}$ content are presented. The method of measuring the small intensities of ionizing radiation, based on measurements $t$-current characteristics $n$-dimensional functions of the distribution of probabilities of time intervals between impulses, which are produced by radiation detectors, are substantiated and experimentally tested. It is shown that the developed method allows to significantly detect radiation with intensities in tens of times lower than the intensity of background radiation, with high intensities of background radiation. The application of the proposed method in dozens decreases the analysis time and reduces the requirements for screening of investigated objects from background radiation.

Keywords: pollution, ionizing radiation, radionuclides, fish.

Постановка проблеми. Забруднення 1 риби відбуваеться шляхом прямого поглинання радіоактивних речовин поверхнею тіла, через їжу і в результаті інших обмінних процесів між організмом і навколишнім середовищем. Радіоактивні елементи проникають у внутрішні органи риб через шкіру, зябра i рот. 
Одним з важливих джерел забруднення риби $\epsilon$ передача радіоактивних речовин через харчові ланцюги. Молода більшість риб і багато дорослих риб харчуються планктоном, який здатний накопичувати радіонукліди до концентрацій в сотні і тисячі разів більше, ніж в навколишній воді. Тому при низькому вмісті радіоактивних речовин у воді їх споживання риби в першу чергу обумовлено зараженою їжею.

При знаходженні у воді, що забруднена радіоактивними речовинами, риби отримають зовнішне опромінення. Адсорбована на поверхні їх тіла активність створюе опромінення організму. У свою чергу радіоактивні речовини, що накопичуються в органах і тканинах, створюють внутрішне джерело опромінення [1-3].

Радіонукліди так само, як і всі стабільні нукліди, надходять в тіло гідробіонтів через травний тракт, зябровий апарат і покривні тканини. Інтенсивність засвоєння організмом радіонуклідів багато в чому визначаеться ступенем фізикохімічної тотожності їх зі стабільними нуклідами, необхідними для оптимального функціонування біонта, а також агрегатним станом, концентрацією у воді, функціональним станом організму, тощо. Живі організми засвоюють нукліди одного елемента практично в рівній мірі, так як за хімічними властивостями вони тотожні.

Інтенсивність надходження в організм радіонукліда в істотній мірі залежить від шляху його проникнення. Радіоактивні речовини, що містяться в твердих частинках, гідробіонтами практично не засвоюються. На відміну від цього радіонукліди, що знаходяться в іонному стані, поглинаються гідробіонтами інтенсивно [2; 4].

Накопичення радіоактивних речовин органами і тканинами риб, а також розподіл і виділення їх залежить від цілого ряду умов, основними 3 яких е: хімічна природа радіоізотопів і періоди їх напіврозпаду, концентрація радіоізотопів у воді, вид, вік і фізіологічний стан риб, екологічні умови.

Кумуляція радіоізотопів органами і тканинами риб залежить від концентрації цих радіоізотопів у воді і часу перебування в ній риб. Чим вище ступінь радіоактивності води, тим більше ступінь забрудненості риб.
При одноразовому забрудненні риб навіть більшими кількостями радіоізотопів накопичення їх в організмі бувае незначним. При тривалому ж забрудненні низькими концентраціями радіоізотопи можуть накопичуватися в організмі у великих кількостях.

Молоді і швидкозростаючі риби кумулюють радіоізотопи швидше і у відносно великих кількостях, ніж риби середнього і старшого віку. У донних риб накопичення радіоізотопів йде швидше, ніж у пелагічних. Таким чином, екологічні умови i piзіологічний стан риб відіграють значну роль в забрудненні їх радіоактивними речовинами $[5 ; 6]$.

Процес накопичення цезію- 137 водними організмами в природних умовах вимагае кількісної оцінки і прогнозування переходу штучних радіонуклідів із зовнішнього середовища в живі організми.

Накопичення радіонуклідів в тканинах багато в чому залежить від фізіологічної активності риби: чим активніше її спосіб життя і чим вона молодша, тим, як правило, більше відкладається в її тканинах радіонуклідів. Інтенсивність накопичення радіонуклідів у риб схильна так само до видовим коливанням.

Вода водойм містить відносно невелику кількість радіонуклідів і виконуе роль екрану, який перешкоджає виносу радіонуклідів 3 донних відкладень. Радіонукліди, що потрапили в річки і озера, осіли на дно, але оскільки водні рослини i безхребетні тварини мають здатність легко накопичувати розчинні у воді мінеральні речовини, в тому числі і радіонукліди, частина їх, головним чином цезій-137 і стронцій-90, концентруеться в гідробіонтах: личинках комах, зоо- і фітопланктоні, водоростях, молюсках [6; 7].

При цьому вимір потоків іонізуючих випромінювань малої інтенсивності є в даний час нетривіальною задачею.

Метою роботи $\epsilon$ виявлення умов накопичення радіоактивних речовин органами і тканинами риб та вимір потоків іонізуючих випромінювань малої інтенсивності.

Виклад основного матеріалу дослідження. Радіонукліди, що надійшли в організм риб, концентруються в залежності від своїх хімічних властивостей в різних органах і тканинах. Це-

Види риб, впорядковані за зростанням середнього рівня вмісту ${ }^{137} \mathrm{Cs}$

Таблиця 1

\begin{tabular}{|l|c|c|c|}
\hline \multicolumn{1}{|c|}{ Вид риби } & Максимальний, Бк/кг & Мінімальний, Бк/кг & Середній, Бк/кг \\
\hline Короп & 10 & 10 & 10 \\
\hline Краснопірка & 79 & 20 & 49,5 \\
\hline Минь & 84 & 17 & 50 \\
\hline Лящ & 105 & 15 & 60 \\
\hline Лин & 112 & 13 & 84 \\
\hline Йорж & 84 & 84 & 202 \\
\hline Канальний сом & 225 & 179 & 275 \\
\hline Рак & 419 & 132 & 424 \\
\hline Карась & 842 & 7 & 603 \\
\hline Плотва & 1193 & 13 & 632 \\
\hline Сом & 1085 & 179 & 650 \\
\hline Щука & 1287 & 14 & 1225 \\
\hline Окунь & 2414 & 36 & \\
\hline
\end{tabular}

Джерело: розроблено авторами за даними [5; 6] 
зій-137, подібний за хімічним складом з калієм, концентруеться в м'язах риб і молюсків, а стронцій-90, який є аналогом кальцію, накопичуеться в кістковій тканині риб і в раковинах молюсків. Відрізняються ці радіонукліди і за швидкістю виведення 3 організму, значно повільніше виводиться стронцій-90, локалізований в кістковій тканині риб і раковинах, цезій-137 порівняно швидко виводиться з м'язів.

Найбільш забруднені цезієм-137 хижі види риб, такі як окунь, щука, сом. Рівень накопичення радіоцезію в організмах цих видів риб змінювався у окуня від 42 до 2414 Бк/кг (сира маса), у щуки - від 14 до 1287 Бк/кг, у сома від 179 до 1085 Бк/кг. Найменш забруднені короп (Cyprinus carpio), краснопірка (Scardinius erythrophthalmus), минь (Lota lota), лин (Tinca tinca). У таблиці 1 наведені деякі види риб, які ранжуються за зростанням середнього рівня вмісту цезію-137 в організмі.

Виявлення потоків іонізуючих випромінювань малої інтенсивності здійснюеться в даний час, як правило, шляхом проведення безперервного спектрального аналізу радіаційної обстановки протягом десятків годин [8; 9]. При цьому в якості детекторів випромінювань, в основному, використовують рідинні або твердотільні сцинтилятори, за допомогою яких виділяють області в енергетичних спектрах, відповідних пікам енергії певних радіонуклідів, i/або вимірюють середню інтенсивність випромінювань (середне число розпадів в одиницю часу).

Для забезпечення необхідної точності результатів вимірювання в спеціальному обладнанні, як наприклад сцинтиляційному спектрометрі енергії бета випромінювання СЕБ-01-70, застосовуеться високоефективний низькофроновий захист (сталь і свинець), який знижуе рівень фронового випромінювання до значень, що не перевищують 0,35 імп/с. Однак час вимірювання, необхідний для досягнення високої достовірності результатів вимірювання, при інтенсивності випромінювань порядку $1 . . .3$ імп/с досягає 24 -х годин.

Методи багатовимірного імовірнісного аналізу і стохастичного посилення дозволяють ефрективно вирішити завдання виміру інтенсивності іонізуючих випромінювань, зменшення впливу природного радіаційного фрону на точність вимірювань і зменшення часу вимірів [10-12].
Нехай $t_{i}, i=\overline{0, N}$ - момент появи $i$-го імпульсу на виході детектора випромінювань, що реєструє іонізуюче випромінювання. Тоді спільна фонкція розподілу ймовірностей того, що інтервали часу між появами кожної пари суміжних імпульсів не перевищують деякого заданого інтервалу часу $T$, має вигляд

$P\left\{t_{k+1}-t_{k}<T, t_{k+2}-t_{k+1}<T, \ldots, t_{k+N+1}-t_{k+N}<T\right\}, k=0,1$,

Відзначимо, що величина, зворотна середньому значенню інтервалу між імпульсами, які надходять 3 детектора випромінювань, являе собою не що інше, як середню інтенсивність випромінювання.

Як показано в роботі [12], завдання вимірювання спільних фрункцій розподілу ймовірностей вирішуеться за допомогою пристрою, структура якого показана на рис. 1.

Виявлене детектором 1 іонізуюче випромінювання перетворюеться в послідовність випадкових у часі імпульсів, що за допомогою фрормувача 2 здобувають фрорму імпульсів однакової тривалості. Ці імпульси далі обробляються в блоці 3 з метою оцінки спільної $N$-мірної фрункції розподілу імовірностей інтенсивності випромінювання. Для цього спочатку вони надходять на один із двох входів блоку 4 вимірювання часових інтервалів (який може бути виконаний, наприклад, на основі лічильника, ПЗП, таймера й ін.), де інтервали їхнього проходження зіставляють 3 наперед заданим періодом часу аналізу $T$ (часовим вікном) 5. Це відповідає алгоритмові

$$
U\left(t_{k}\right)=\left\{\begin{array}{lll}
1, & \text { nрu } & t_{k+1}-t_{k}<T, \\
0, & \text { прu } \quad t_{k+1}-t_{k} \geq T, \quad k=0,1, \ldots .
\end{array}\right.
$$

Отримана в результаті порівняння цифрова послідовність $U\left(t_{k}\right)$ запам'ятовується в $N$-розрядному регістрі 6 . Сигнали, що знімаються 3 рівнобіжних виходів регістра надходять на $N$-входовий елемент 7 збігу, що фрормує процес

$$
Y\left(t_{k+1}, t_{k}, \ldots, t_{k+1-(N-1)}\right)=\bigcap_{i=k+1-(N-1)}^{i=k+1} U\left(t_{i}\right), \quad k=0,1, \ldots .
$$

Сигнал, отриманий у результаті збігу, подається в накопичуючий суматор 8 ( $t$-поточний інтегратор), що формує ощінку спільної $N$-вимірної функції розподілу імовірностей інтенсивності випромінювання

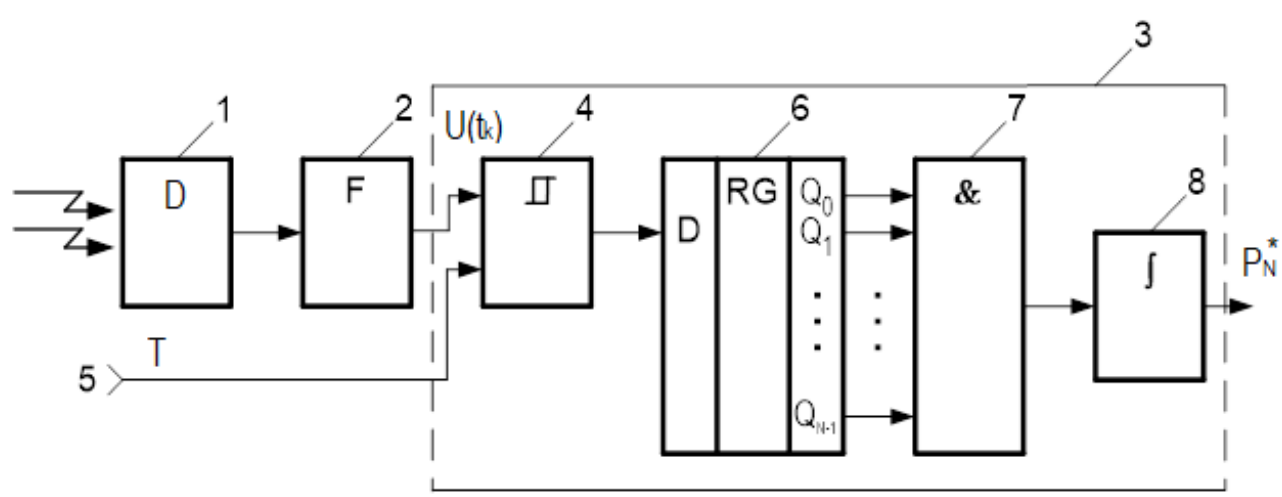

Рис. 1. Структурна схема вимірювача сумісних $N$-вимірних функцій розподілу імовірностей інтенсивності випромінювання 


$$
P^{*}\left\{t_{k+1}-t_{k}<T, t_{k+2}-t_{k+1}<T, \ldots, t_{k+N}-t_{k+N-1}<T\right\}=\frac{1}{M} \sum_{i=k-M+1}^{i=k} Y\left(t_{i}, t_{i-1}, \ldots, t_{i-N+1}\right), k=0,1, \ldots
$$

де $M$ - постійна накопичення.

Принцип роботи $t$-поточного інтегратора описаний, наприклад, у [13, с. 59-76]. Якщо позначити довірчий інтервал $\delta$ (асоційований 3 роздільною здатністю), а довірчу імовірність $P_{\delta}$, то, наприклад, при $\delta \sqrt{M}=1,5, P_{\delta} \leq 0,01$,
$M \approx 10000$, вимірювач забезпечуе роздільну здатність по фрункції розподілу імовірностей не гірше 1,5\%.

Як показано в роботі [12], довірчий інтервал $\delta$ і довірча імовірність $P_{\delta}$ для оцінок типу (4) пов'язані між собою співвідношенням

$$
P_{\delta}=P\left\{\left|P_{N}^{*}\left(t_{k+1}-t_{k}<T, k=\overline{0, N}\right)-P_{N}\left(t_{k+1}-t_{k}<T, k=\overline{0, N}\right)\right|>\delta\right\} \leq \frac{0,25}{M \delta^{2}},
$$

де $P_{N}\left(t_{k+1}-t_{k}<T, k=\overline{0, N}\right)-$ справжне значення фоннкції розподілу. 3 умови (5) видно, що його права частина залежить тільки від постійної накопичення $M$ і величини довірчого інтервалу $\delta$, а це дозволяе оџінювати достовірність результатів вимірювань незалежно від виду розподілу ймовірностей досліджуваних процесів і виду розподілу самої оцінки (5). Важливо відзначити, що 3 незалежності довірчої ймовірності $P_{\delta}$ від розподілу інтервалів між імпульсами випливає, що при вимірюванні функцій розподілу ймовірностей інтенсивності випромінювання можна обмежитися обробкою такого числа $M$ імпульсів, яке при заданій довірчій ймовірності $P_{\delta}$ забезпечуе необхідну роздільну здатність $\delta$.

Для перевірки запропонованої методики було проведено кілька серій експериментів 3 вимірювання $t$-поточної характеристики $n$-вимірної фрункції розподілу ймовірностей часових інтервалів між імпульсами, що виробляється детектором випромінювань. Вимірювалися одно-, трьох- і п'ятивимірні характеристики фрункції розподілу ймовірностей для фонового випромінювання, за відсутності джерела випромінювання і при його наявності. При цьому рівень випромінювання джерела становив 2\%, 4\% і 8\% рівня фонового випромінювання. Результати вимірювань показані на рис. 2-4.

На цих рисунках по осі абсцис відкладено число імпульсів, що надходять на вимірювач $t$-поточних характеристик $n$-вимірних функцій розподілу ймовірностей 3 детектора випромінювань, а по осі ординат значення відповідних характеристик. Значення аргументу $T$ вибиралося рівним середньому значенню часових інтервалів між імпульсами фонового випромінювання. В описуваних серіях експериментів цей час дорівнює 0,1 с, що відповідає інтенсивності фону майже в 30 разів більше, ніж допустима інтенсивність фрону при вимірах за допомогою серійного спектрометра СЕБ-01-70. Очевидно, що середньому часовому інтервалу 0,1 с відповідає середня інтенсив- Джерело: розроблено авторами

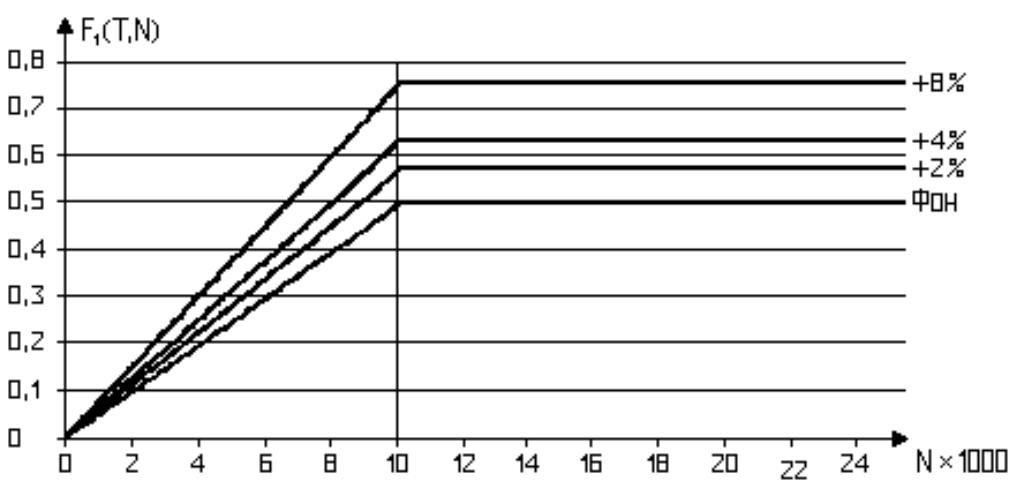

Рис. 2. Одновимірна характеристика функції розподілу імовірностей

Джерело: розроблено авторами

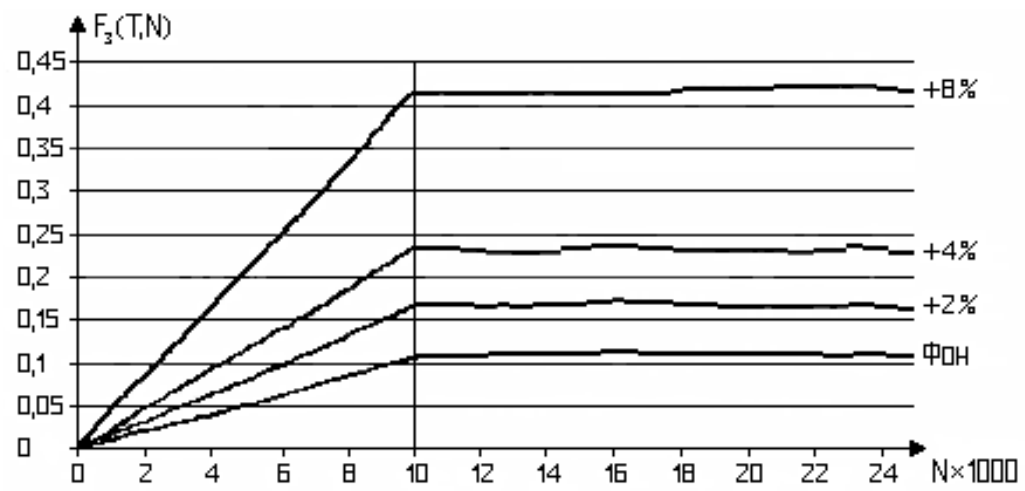

Рис. 3. Трьохвимірна характеристика функції розподілу імовірностей

Джерело: розроблено авторами

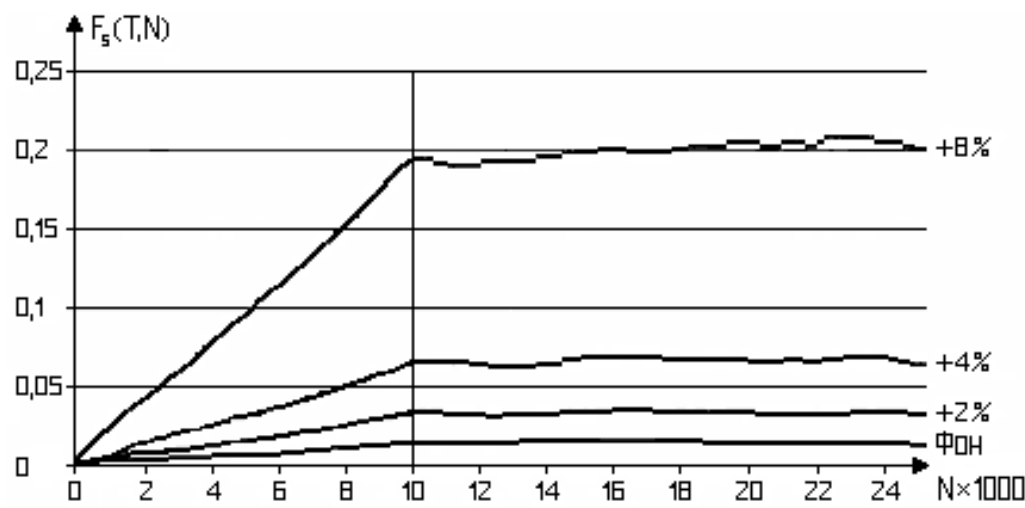

Рис. 4. П'ятивимірна характеристика функції розподілу імовірностей 
ність імпульсів фрону 10 імп/с. На всіх рисунках проміжок значень $N=0 \ldots 10000$ відповідае часу встановлення пристрою, що вимірюе відповідні характеристики $n$-вимірних фонкцій розподілу ймовірностей.

Багатовимірні фрункції розподілу ймовірностей $є$ досить ефрективним засобом для виявлення випромінювань, інтенсивність яких у багато разів менше інтенсивності фонового випромінювання. В даний час при виконанні датування по інтенсивності випромінювання ізотопу ${ }^{14} \mathrm{C}$ потрібна точність результатів не гірше 1\%. Для отримання такої точності при досить великої довірчої ймовірності, відповідно до теорії прийняття статистичних рішень $[11 ; 14]$ необхідно отримати щонайменше 10000 імпульсів випромінювання. При середній інтенсивності $10 \ldots 20$ розпадів за хвилину це призводить до того, що вимірювання повинні проводитися цілодобово. Це, в свою чергу, призводить до проблем, пов'язаних зі стабільністю параметрів апаратури, а також екранування джерел випромінювання, для забезпечення високого відношення сигнал/фрон. Вимірювання одно-, трьох- і п'яти вимірних характеристик фрунцій розподілу ймовірностей дозволяють впевнено виявляти джерела випромінювання, інтенсивність яких в 50 разів менше інтенсивності фонового випромінювання. Тобто пропонована методика дозволяе аналізувати проби при значно більш високих рівнях фронового випромінювання, в порівнянні з відомими методиками, що, в свою чергу, дозволяе істотно знизити вимоги до захисту з низьким рівнем фону, i, відповідно, зменшити матеріалоємність і вагу застосовуваних захисних екранів.

3 іншого боку, з нерівності (5) випливає, що необхідна точність і достовірність результатів вимірювань фрактично повністю визначається числом імпульсів $M$, що надходять на вимірювач характеристик $n$-вимірних фрункцій розподілу ймовірностей з виходу детектора випромінювань, і не залежить від часу, протягом якого ці імпульси надходять на вимірювач. Це дозволяе виконува- ти вимірювання при високих, порядку десятків імпульсів в секунду, інтенсивностях фонового випромінювання і автоматично призводить до істотного (в десятки разів) зменшення часу експозиції проб в порівнянні з відомими методами. 3 результатів вимірювань також випливає, що збільшення мірності вимірюваних характеристик фрункщій розподілу ймовірностей призводить до збільшення відносної чутливості вимірювань. При збільшенні інтенсивності випромінювання на 8\%, тобто при збільшенні інтенсивності потоку імпульсів в 1,08 рази одновимірна характеристика фрункції розподілу ймовірностей зростає в 1,25 рази, тривимірна - в 3,5 рази, а п'ятивимірна - приблизно в 10 разів. Зауважимо, що такий характер змін багатовимірних фрункцій розподілу ймовірностей тісно пов'язаний 3 описаним в [15] ефректом стохастичного посилення.

\section{Висновки.}

1. Інтенсивність засвоєння рибами радіонуклідів визначається ступенем фізико-хімічної тотожності їх зі стабільними нуклідами.

2. Накопичення радіоізотопів органами і тканинами риб залежить від концентрації їх у воді і часу перебування в ній риб.

3. Наведено деякі види риб, впорядковані за зростанням середнього рівня вмісту ${ }^{137} \mathrm{Cs}$.

4. Запропоновано, обгрунтовано та експериментально перевірено методику вимірювання малих інтенсивностей іонізуючих випромінювань, засновану на вимірі $t$-поточних характеристик $n$-вимірних фоункцій розподілу ймовірностей часових інтервалів між імпульсами, що виробляються детекторами випромінювань.

5. Показано, що розроблена методика дозволяе достовірно виявляти випромінювання 3 інтенсивностями в десятки разів нижче інтенсивності фонових випромінювань, при високих інтенсивностях фонового випромінювання.

6. Застосування пропонованої методики істотно зменшує (в десятки разів) час аналізу і знижуе вимоги до екранування досліджуваних об'єктів від фронового випромінювання.

\section{Список літератури:}

1. Хомутинин Ю.В., Кашпаров В.А., Кузьменко А.В. Зависимость коэффициентов накопления ${ }^{137} \mathrm{Cs}$ и ${ }^{90} \mathrm{Sr}$ рыбой от содержания калия и кальция в воде пресноводного водоема. Радиационная биология. Радиоэкология. 2011. T. 51. № 3. C. 374-384.

2. Трапезникова В.Н., Трапезников А.В. Радиоэкология пресноводных экосистем как научная дисциплина. Вопросы радиаиионной безопасности. 2006. № 1(41). С. 35-58.

3. Смирнов С.Н., Герасимов Д.Н. Радиационная экология. Физика ионизирующих излучений. Москва : Издательский дом МЭИ, 2006. 326 с.

4. Василенко О.И. Радиационная экология. Москва : Медицина, 2004. 216 с.

5. Вербельчук С.П. Аналіз рівня забруднення ${ }^{137} \mathrm{Cs}$ та ${ }^{90} \mathrm{Sr}$ прісноводної риби та її внесок у формування дози внутрішнього опромінення сільських споживачів. Вісник ДАУ. 2003. № 1. С. 301-306.

6. Волкова О.М. Формування радіонуклідного забруднення іхтіофауни прісноводних водойм України. Наук. вісник Національного аграрного університету. Київ, 2006. № 102. С. 53-60.

7. Беляев В.В., Волкова Е.Н., Скиба В.В. Определение скорости поступлення ${ }^{90} \mathrm{Sr}$ и ${ }^{137} \mathrm{Cs}$ в организм пресноводных рыб. Гидробиологический журнал. 2011. Т. 47. № 4. С. 112-120.

8. Силантьев А.Н. Спектрометрический анализ радиоактивных проб внешней среды. Ленінград : Гидрометеорологическое изд-во, 1969. 183 с.

9. Stuiver M., Reimer P.J., Braziunas T.F. High-precision radiocarbon age calibration for terrestrial and marine samples. Radiocarbon. 1998. Vol. 40. P. 1127-1151.

10. Даджион Д., Мерсеро Р. Цифровая обработка многомерных сигналов : Пер. с англ. Москва : Мир, 1988.488 с.

11. Корн Г., Корн Т. Справочник по математике для научных работников и инженеров. Москва : Наука, 1984. $832 \mathrm{c}$.

12. Брягин О.В., Егоров А.К., Розоринов Г.Н. Об оценке многомерных функций распределения вероятностей речевых сигналов. Реєстрація, зберігання і обробка даних. 2004. Т. 6. № 3. С. 41-49.

13. Мирский Г.Я.. Апаратурное определение характеристик случайных процессов. Москва : Энергия, 1972.456 с.

14. Левин Б.Р. Теоретические основы статистической радиотехники. Кн. 2. Москва : Сов. радио, 1968.552 с. 
15. Егоров А.К., Розоринов Г.Н. Стохастическое усиление управляющих сигналов. Вісник Державного університету інборлаиійно-колунікаційних технологій. 2004. Т. 2. № 1. С. 45-47.

\section{References:}

1. Khomutinin Yu.V., Kashparov V.A., Kuz'menko A.V. (2011) Zavisimost' koefitsientov nakopleniya ${ }^{137} \mathrm{Cs}$ i ${ }^{90} \mathrm{Sr}$ ryboy ot soderzhaniya kaliya i kal'tsiya v vode presnovodnogo vodoema. Radiatsionnaya biologiya. Radioekologiya, vol. 51, no. 3, pp. 374-384.

2. Trapeznikova V.N., Trapeznikov A.V. (2006) Radioekologiya presnovodnykh ekosistem kak nauchnaya distsiplina. Voprosy radiatsionnoy bezopasnosti, no. 1(41), pp. 35-58.

3. Smirnov S.N., Gerasimov D.N. (2006) Radiatsionnaya ekologiya. Fizika ioniziruyushchikh izlucheniy. Moscow: Izdatel'skiy dom MEI, 326.

4. Vasilenko O.I. (2004) Radiatsionnaya ekologiya. Moscow: Meditsina, 216.

5. Verbel'chuk S.P. (2003) Analiz rivnya zabrudnennya ${ }^{137} \mathrm{Cs}$ ta ${ }^{90} \mathrm{Sr}$ prisnovodnoi ryby ta yii vnesok u formuvannya dozy vnutrishnoho oprominennia silskykh spozhyvachiv. Visnyk DAU, no. 1, pp. 301-306.

6. Volkova O.M. (2006) Formuvannia radionuklidnoho zabrudnennia ikhtiofauny prisnovodnykh vodoim Ukrainy. Nauk. visnyk Natsionalnoho ahrarnoho universytetu, no. 102, pp. 53-60.

7. Beliaev V.V., Volkova E.N., Skiba V.V. (2011) Opredelenie skorosti postuplennia ${ }^{90} \mathrm{Sr}$ i ${ }^{137} \mathrm{Cs}$ v organizm presnovodnykh ryb. Gidrobiologicheskii zhurnal, vol. 47, no. 4, pp. 112-120.

8. Silant'ev A.N. (1969). Spektrometricheskii analiz radioaktivnykh prob vneshnei sredy. Leningrad : Gidrometeorologicheskoe izd-vo, $183 \mathrm{p}$.

9. Stuiver M., Reimer P.J., Braziunas T.F. (1998) High-precision radiocarbon age calibration for terrestrial and marine samples. Radiocarbon, vol. 40, pp. 1127-1151.

10. Dadzhion D., Mersero R. (1988) Tcifrovaia obrabotka mnogomernykh signalov. Moscow: Mir, 488 p.

11. Korn G., Korn T. (1984) Spravochnik po matematike dlia nauchnykh rabotnikov i inzhenerov. Moscow: Nauka, 832 p.

12. Briagin O.V., Egorov A.K., Rozorinov G.N. (2004) Ob otcenke mnogomernykh funktcii raspredeleniia veroiatnostei rechevykh signalov. Reiestratsiia, zberihannia i obrobka danykh, vol. 6, no. 3, pp. 41-49.

13. Mirskii G.Ya. (1972) Aparaturnoe opredelenie kharakteristik sluchainykh protcessov. Moscow: Energiia, 456 p.

14. Levin B.R. (1968) Teoreticheskie osnovy statisticheskoi radiotekhniki. Kn. 2. Moscow: Sov. Radio, 552 p.

15. Egorov A.K., Rozorinov G.N. (2004) Stokhasticheskoe usilenie upravliaiushchikh signalov. Visnyk Derzhavnoho universytetu informatsiino-komunikatsiinykh tekhnolohii, vol. 2, no. 1, pp. 45-47. 